Vol.1, No.1, Desember 2017

E-mail: jpsp@unpad.ac.id

\title{
PERAN KUALITAS KEHIDUPAN KERJA DAN PERSEPSI PELUANG KERJA TERHADAP INTENSI PINDAH KERJA
}

\author{
Yudhistira Victoria, Zamralita, Kiky D. H. Saraswati \\ Universitas Tarumanagara \\ yudhistira.victoria@gmail.com
}

\begin{abstract}
ABSTRAK
Perubahan hidup dan zaman membuat perubahan-perubahan dalam aspek kerja. Tujuan dari penelitian ini adalah menganalisis peran dari kualitas kehidupan kerja dan persepsi peluang kerja terhadap intensi pindah kerja karyawan PT. X berperan terhadap intensi pindah kerja. Intensi pindah kerja adalah keinginan individu untuk keluar dari keanggotan suatu organisasi dan berpindah ke organisasi lain dimana keinginan tersebut belum diwujudkan dalam tindakan pasti meninggalkan organisasi tempat karyawan bekerja. Kualitas kehidupan bekerja adalah persepsi pekerja terhadap suasana dan pengalaman pekerja di tempat kerja mereka. Sedangkan persepsi terhadap peluang kerja adalah proses tanggapan yang terjadi dalam diri individu terhadap keadaan pasar tenaga kerja. Tinggi dan rendahnya kesesuaian keadaan antara pencari kerja dan pekerjaan yang ditawarkan akan menentukan besarnya intensi karyawan untuk meninggalkan organisasi. Penelitian ini melibatkan 300 responden yang merupakan karyawan PT. X. Metode survei secara online melalui portal karyawan berbentuk closed-ended question diberikan kepada responden. Data dianalisis dengan menggunakan regresi linear ganda. Hasil penelitian menunjukkan nilai $\mathrm{F}$ sebesar 70,780 dengan signifikansi $(p)$ sebesar $0,000(p<0,05)$ dan nilai $R^{2}$ sebesar 0,323 yang berarti terdapat peran yang signifikan antara kualitas kehidupan kerja dan persepsi peluang kerja terhadap intensi pindah kerja karyawan di PT. $X$ dengan kontribusi sebesar 32,3\%. Intervensi yang dilakukan adalah menyusun program pelatihan dan memperbaikan uraian pekerjaan sesuai dengan kebutuhan perusahaan saat ini.
\end{abstract}

Kata Kunci : kualitas kehidupan kerja, persepsi peluang kerja, intensi pindah kerja

\begin{abstract}
There are many change in a lot of aspects of work. The purpose of this research is to analyze the impact of quality of work life and the perception of job opportunities towards employee turnover intention at PT. FG and to analyze each variable to know which variable contributes more impact towards employee turnover intention. Turnover intention is the termination of the process of an individual obtaining material income from the organization. Quality of work life is the perception of the workers of the atmosphere and the experience of workers in their workplace. While the perception of job opportunities is a process that formed the response that occurs in the individual against the state of the labor market. High and low compliance the situation between job seekers and job that offered will determine the amount of attention employees to leave the organization. This research involved 300 respondents. Online survey method was used to collect the data. Data was analyzed using multiple linear regression. The results of the study showed the value of $F$ of 70,780 with the significance $(p)$ of 0,000 $(p<0.05)$ and $R$ Square $=0,323$ which means there is a significant impact of the quality of life of work life and the perception of job opportunities towards employees turnover intention at PT. FG with contribution of 32,3\%. The intervention are arranging training and job description for all position based on company needs.
\end{abstract}

Keywords: quality of work life, perception of job opportunities, turnover intention 


\title{
Journal of Psychological Science and Profesion (JPSP)
}

\author{
Vol.1, No.1, Desember 2017 \\ E-mail: jpsp@unpad.ac.id
}

\section{PENDAHULUAN}

Sejak awal tahun 2000-an media online banyak bermunculan. Eksistensi media cetak yang dahulu menyuguhkan berita-berita terkini, pelan-pelan tergeser dengan keberadaan media online. Dulu media cetak seperti koran, majalah dan tabloid menjadi acuan masyarakat dalam mendapatkan informasi terkini tentang peristiwa yang terjadi di sekitar mereka maupun di dunia internasional. Kini masyarakat lebih memilih mengakses media online untuk mengetahui berita maupun perkembangan terbaru.

Ambruknya perusahaan surat kabar di Amerika Serikat (AS) juga bukan disebabkan oleh buruknya kualitas jurnalisme, tetapi lebih karena berkurangnya pembeli surat kabar edisi cetak yang mengakibatnya berkurangnya pendapatan iklan melalui surat kabar edisi cetak. Keadaan ini pun berdampak pada perusahaan media cetak lainnya di Indonesia. Contoh di Indonesia terjadi pada majalah Tempo, yang harus melakukan pembaharuan untuk dapat bersaing dengan media digital lainnya, yaitu dengan membuat format digital seperti korantempo.com, tempo.com, dan majalah digital dengan akses berbayar.

Kasus serupa juga terjadi di PT. X, salah satu perusahaan media cetak tertua di Indonesia. PT. $X$ tidak mampu mengantisipasi persaingan yang ada dengan perusahaan media digital lainnya. Oleh karena itu untuk dapat bertahan PT. X harus merubah strategi yang berhubungan dengan bisnis dan sumber daya manusia perusahaan. Perubahan strategi ini antara lain penggabungan beberapa majalah menjadi satu majalah, perampingan struktur organisasi di setiap majalah, mutasi karyawan antar bagian, pemotongan budget terkait dengan fasilitas yang diberikan perusahaan kepada karyawan, serta penambahan tanggung jawab pekerjaan pada beberapa posisi manajerial. Mutasi yang dilakukan oleh perusahaan serta penambahan tanggung jawab kepada beberapa posisi membuat uraian tanggung jawab pekerjaan menjadi berubah dan karyawan menjadi tidak memahami uraian pekerjaannya masing-masing. Selain itu pemotongan budget terkait dengan benefit karyawan mengharuskan karyawan tidak mengalami kenaikan gaji dan pembayaran gaji menjadi dibayar secara angsuran oleh perusahaan. Perubahan-perubahan strategi yang dilakukan PT. $\mathrm{X}$ dapat diduga merupakan bagian dari dimensi-dimensi yang dimiliki oleh kualitas kehidupan kerja. Adanya perubahan strategi ini dapat membuat karyawan merasa tidak nyaman sehingga memiliki keinginan untuk pindah kerja.

Berdasarkan penelitian yang dilakukan sebelumnya terkait dengan kualitas kehidupan kerja, sebagian besar penelitian selalu berkaitan dengan intensi pindah kerja. Seperti penelitian yang dilakukan oleh Mosadeghrad (2013), hasil penelitian menyatakan bahwa kualitas kehidupan kerja memiliki peran terhadap intensi pindah kerja karyawan. Penelitian dilakukan kepada karyawan Rumah Sakit Pemerintah dan Rumah Sakit Swasta di Iran dengan kontribusi peran kualitas kehidupan kerja adalah $44 \%$ terhadap intensi pindah kerja. Adapun dimensi kualitas kehidupan kerja yang paling berperan terhadap intensi pindah kerja adalah management support dengan kontribusi peran sebesar $82 \%$ dan nilai mean 2,27 (skala 1-5) serta participation and involvement dengan kontribusi peran sebesar $81 \%$ dan nilai mean 2,32 (skala 1-5).

Penelitian yang dilakukan oleh Rokhman (2013) juga mengatakan bahwa kualitas kehidupan kerja memiliki peran terhadap intensi pindah kerja karyawan pada BMT di Kudus. Adapun peran yang dimiliki adalah negatif, artinya semakin tinggi kualitas kehidupan kerja karyawan dalam suatu organisasi akan menurunkan keinginan karyawan untuk pindah kerja ke perusahaan lain. Dimensi kualitas kehidupan kerja yang memiliki peran paling besar terhadap intensi pindah kerja adalah kesejahteraan dan pengembangan.

Selain itu penelitian Kumar dan Thomas (2016) juga meneliti mengenai peran kualitas kehidupan kerja terhadap intensi pindah kerja pada karyawan Rumah Sakit Swasta di India. Hasil penelitian menunjukkan kualitas kehidupan kerja memiliki peran terhadap intensi pindah kerja pada karyawan Rumah Sakit Swasta di India dengan kontribusi peran adalah $46 \%$. Kualitas kehidupan kerja yang rendah dengan nilai mean 2,38 (skala 1-5) mengakibatkan tingginya intensi pindah kerja karyawan. Dimensi kualitas kehidupan kerja yang memiliki peran paling besar terhadap intensi pindah kerja adalah management support, job characteristic, job security, job stress, dan promotion policy dengan kontribusi peran adalah $78 \%$.

Penelitian lain yang juga meneliti peran kualitas kehidupan kerja dan intensi pindah kerja adalah Almalki, Gerald, dan Clark (2012) terhadap suster yang bekerja di pelayanan kesehatan di Arab Saudi. Hasil penelitian menunjukkan bahwa kualitas kehidupan kerja memiliki peran terhadap intensi pindah kerja dengan kontribusi peran $26 \%$. 


\title{
Journal of Psychological Science and Profesion (JPSP)
}

\author{
Vol.1, No.1, Desember 2017 \\ E-mail: jpsp@unpad.ac.id
}

Menurut Walton (1973), dimensi yang dimiliki oleh kualitas kehidupan kerja ada 8 dimensi, yaitu pay and benefits, working condition, personal development, promotion, co-worker, work culture, work life balance, dan social relevance of employer. Berdasarkan keadaan PT. X, dimensi kualitas kehidupan kerja yang diduga memiliki peran terhadap intensi pindah kerja adalah yang berhubungan dengan pay and benefits, job characteristic, dan personal development.

Selain kualitas kehidupan kerja, faktor di luar perusahaan juga memiliki peran terhadap intensi pindah kerja karyawan. Banyaknya perusahaanperusahaan media digital baru yang menjadi pesaing PT. $X$ dapat menarik minat karyawan untuk pindah kerja. Perusahaan-perusahaan akan saling bersaing untuk mendapatkan tenaga kerja terbaik, sebaliknya tenaga kerja juga akan bersaing untuk mendapatkan perusahaan yang terbaik (Hariandja, 2002).

Penelitian sebelumnya mengenai persepsi peluang kerja terhadap intensi pindah kerja adalah penelitian yang dilakukan oleh Laker (2011) terhadap alumni dari berbagai universitas di Eropa yang sedang bekerja di berbagai jenis perusahaan. Hasil penelitian ini menjelaskan bahwa persepsi mengenai peluang kerja di luar perusahaan memiliki peran terhadap intensi pindah kerja karyawan dengan kontribusi peran $47 \%$.

Selain itu, Treuren (2013) juga melakukan penelitian mengenai peran persepsi peluang terhadap intensi pindah kerja pada pegawai swasta dengan profesi yang bervariasi. Penelitian dilakukan dua kali dengan periode waktu yang berbeda. Hasil penelitian menunjukkan hasil yang konsisten antara periode pertama dan kedua dan jika disatukan, yaitu persepsi peluang kerja memiliki peran terhadap intensi pindah kerja dengan kontribusi peran $28 \%$.

Berdasarkan penelitian yang sudah dijelaskan sebelumnya, menunjukkan bahwa persepsi peluang juga merupakan variabel yang dapat berperan terhadap intensi pindah kerja. Kedua penelitian tersebut semuanya dilakukan terhadap berbagai macam profesi pekerjaan dan latar belakang perusahaan yang bervariasi. Adanya karakteristik sampel yang sama dapat memungkinkan munculnya hasil penelitian yang sama. Jika dilihat dengan keadaan di PT. X, dapat diduga persepsi peluang kerja memiliki peran terhadap intensi pindah kerja.

Berdasarkan uraian dan keadaan di PT. X maka peneliti akan melakukan penelitian mengenai peran kualitas kehidupan kerja dan persepsi peluang kerja terhadap intensi pindah kerja. Masing-masing variabel tersebut dapat menjadi faktor yang berdiri sendiri ataupun saling berkaitan hingga menyebabkan karyawan memiliki keinginan untuk meninggalkan perusahaan. Hasil penelitian saat ini juga hanya menjelaskan mengenai peranan kualitas kehidupan kerja terhadap intensi pindah kerja atau peranan persepsi peluang kerja terhadap intensi pindah kerja, namun sejauh ini belum ada hasil penelitian yang menjelaskan mengenai peranan kualitas kehidupan kerja dan persepsi peluang kerja terhadap intensi pindah kerja di perusahaan. Oleh karena itu peneliti juga akan meneliti mengenai seberapa besar peran kedua faktor tersebut secara bersamaan sehingga menimbulkan intensi pindah kerja pada karyawan di PT. X.

Mobley (1986) mengartikan pindah kerja sebagai pemberhentian keanggotaan individu dalam suatu organisasi baik secara sukarela dari dalam diri individu itu sendiri maupun secara tidak sukarela yang pemberhentian tersebut berasal dari organisasi dimana individu tersebut bekerja.

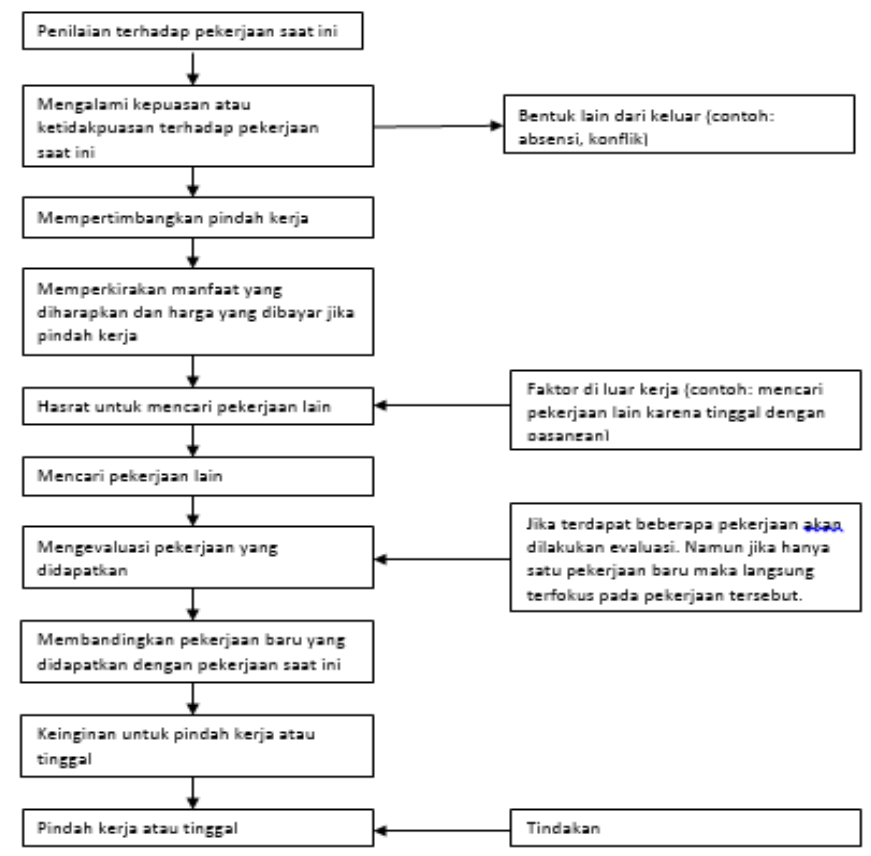

Gambar 1. Perilaku pindah kerja (Mobley, 1986)

Walton (1973) mendefinisikan kualitas kehidupan bekerja sebagai persepsi pekerja terhadap suasana dan pengalaman pekerja di tempat kerja mereka. 


\title{
Journal of Psychological Science and Profesion (JPSP)
}

\author{
Vol.1, No.1, Desember 2017
}

E-mail: jpsp@unpad.ac.id

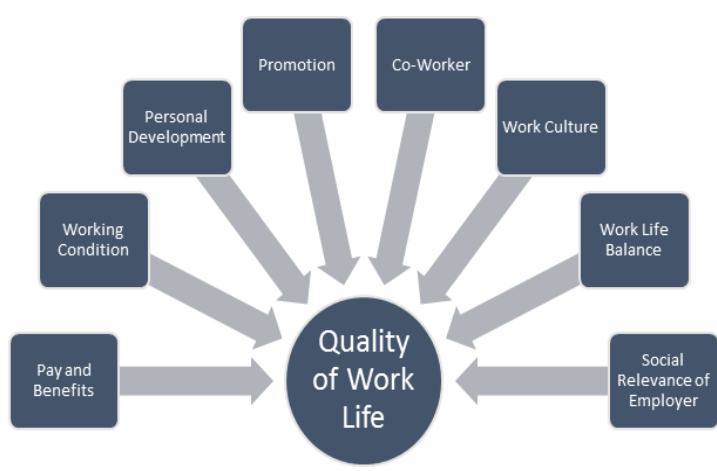

Gambar 2. Dimensi kualitas kehidupan kerja (Walton, 1973)

Persepsi terhadap peluang kerja adalah proses yang dimulai dari penglihatan hingga terbentuk tanggapan yang terjadi dalam diri individu terhadap keadaan pasar tenaga kerja. Tinggi dan rendahnya kesesuaian keadaan antara pencari kerja dan pekerjaan yang ditawarkan akan menentukan besarnya intensi karyawan untuk meninggalkan organisasi (Allen, Bryant, \& Vardaman, 2010).

Karyawan dalam suatu perusahaan mempersepsikan bahwa ketika individu bekerja sesuai dengan yang ditentukan perusahaan, maka individu akan memperoleh imbalan atau penghargaan atas hasil kineranya. Hasil dari persepsi individu terhadap imbalan atau penghargaan yang diterimanya akan membentuk suatu perilaku yang merupakan respon terhadap perilaku yang dilakukan oleh perusahaan. Sehingga keadaan tersebut membentuk terjadinya hubungan timbal balik.

Penjelasan tersebut sesuai dengan Social Exchange Theory (Teori Pertukaran Sosial) yang diperkenalkan oleh George C Homans (1958). Homans (1958) memandang bahwa perilaku adalah pertukaran aktivitas ternilai ataupun tidak dan kurang lebih menguntungkan atau mahal bagi dua orang yang saling berinteraksi. Teori pertukaran ini berusaha menjelaskan tentang perilaku dasar berdasarkan imbalan dan biaya.

Ketika karyawan sudah bekerja dengan baik dan memperoleh kenaikan gaji yang sesuai, pelatihan sesuai dengan pekerjaannya, fasilitas kesejahteraan yang lengkap, dan hal lainnya yang diharapkan karyawan maka karyawan akan memunculkan perilaku bekerja yang diharapkan perusahaan yaitu salah satunya adalah tidak mengundurkan diri dari perusahaan. Karyawan merasa bahwa kualitas kehidupan kerja nya terjamin sehingga dampaknya karyawan bekerja dengan lebih baik lagi dan tidak mengundurkan diri dari perusahaan. Sedangkan permasalahan yang terjadi saat ini adalah banyak karyawan yang mengundurkan diri dan jika berdasarkan teori pertukaran sosial keadaan ini dapat dikarenakan imbalan dari perusahaan yang tidak sesuai dengan harapan karyawan, dimana imbalan merupakan alat ukur dari kualitas kehidupan kerja karyawan.

Berdasarkan penjelasan tersebut maka peneliti akan meneliti peran kualitas kehidupan kerja karyawan terhadap intensi pindah kerja karyawan. Hipotesis pertama adalah: Kualitas kehidupan kerja berperan terhadap intensi pindah kerja pada karyawan PT. X.

Selain kualitas kehidupan kerja yang menjadi faktor intenal karyawan mengundurkan diri, maka terdapat juga faktor eksternal yang mempengaruhi intensi pindah kerja karyawan. Faktor tersebut adalah persepsi karyawan terhadap peluang kerja di luar perusahaan. Faktor ini juga merupakan alasan paling banyak karyawan mengundurkan diri dari perusahaan.

Oleh karena itu berdasarkan penelitian yang telah dilakukan sebelumnya, peneliti mencoba melakukan penelitian mengenai peran persepsi peluang kerja terhadap intensi pindah kerja karyawan di perusahaan media cetak. Hipotesis kedua adalah: Persepsi peluang kerja berperan terhadap intensi pindah kerja pada karyawan PT. $\mathrm{X}$.

Dengan adanya faktor internal dan eksternal yang dapat membentuk intensi karyawan untuk pindah kerja dari perusahaan, maka peneliti akan melihat peran kedua faktor tersebut secara bersamaan terhadap intensi pindah kerja karyawan. Hipotesis ketiga adalah: Kualitas kehidupan kerja dan persepsi peluang kerja berperan terhadap intensi pindah kerja pada karyawan PT. X.

\section{METODE}

Pada penelitian ini kriteria partisipan yang digunakan adalah karyawan PT. $X$ yang berjumlah tujuh ratus lima puluh orang. Status karyawan tetap dengan masa kerja lebih dari dua tahun yang berada di bagian Support, Bisnis, dan Editorial. Jumlah populasi sebesar tujuh ratus lima puluh orang berdasarkan perhitungan pada tabel krecjie dengan derajat signifikansi $5 \%$, maka jumlah sampel yang dapat diambil sejumlah tiga ratus orang dengan demografi berdasarkan usia, masa kerja, jenis kelamin, jabatan, departemen, pendidikan terakhir, dan status pernikahan. Berdasarkan hasil tersebut jumlah sampel per departemen adalah empat puluh enam orang 


\title{
Journal of Psychological Science and Profesion (JPSP)
}

\author{
Vol.1, No.1, Desember 2017 \\ E-mail: jpsp@unpad.ac.id
}

untuk departemen Support dengan persentase 15 $\%$, tujuh puluh tiga orang untuk departemen Bisnis dengan persentase $24 \%$, dan seratus delapan puluh satu orang untuk departemen Editorial dengan persentase $60 \%$.

Pendekatan penelitian yang digunakan adalah pendekatan kuantitatif non eksperimental. Dilihat dari waktu pengambilan datanya, penelitian ini tergolong ke dalam penelitian cross sectional. Penelitian cross sectional merupakan tipe penelitian yang memotret suatu kelompok sampel hanya pada satu waktu tertentu. Penelitian ini menggunakan metode survei yang dilakukan secara online melalui portal karyawan berbentuk closed-ended question kepada responden. Lokasi dalam penelitian ini dilakukan di PT. $X$ yang bertempat di daerah Setiabudi, Jakarta Selatan.

Instrumen ukur yang digunakan adalah pengumpulan data primer yaitu angket atau kuesioner. Alat ukur kualitas kehidupan kerja merupakan alat ukur yang diadaptasi dari definisi Walton (1973). Menurut Walton (1973), pengukuran terhadap kualitas kehidupan kerja berdasarkan 8 dimensi yang terdiri dari pay and benefits, working condition, personal development, promotion, co-worker, work culture, work life balance, dan social relevance of employer. Adapun berdasarkan penelitian terakhir oleh Rostiana, Zamralita, \& Suyasa (2014) menambahkan dua dimensi lain yaitu supervisory dan job characteristic. Alat ukur ini terdiri dari empat puluh tujuh butir yang memiliki sepuluh dimensi kualitas kehidupan kerja. Alat ukur yang dikembangkan oleh Universitas Tarumanagara (2014) ini menggunakan skala 1-5 dengan arti sebagai berikut 1 (satu) adalah Buruk, 2 (dua) adalah Kurang, 3 (tiga) adalah Cukup, 4 (empat) adalah Baik, dan 5 (lima) adalah Istimewa. Peneliti tetap mempertahankan nilai 0 (nol) sebagai representatif dalam pilihan Tidak Ada / Tidak Tahu.

Alat ukur persepsi peluang kerja yang digunakan adalah yang dikembangkan oleh peneliti sebelumnya yaitu Putri, A.D (2013). Alat ukur persepsi peluang kerja ini terdiri dari sepuluh butir yang terdiri dari pernyataan favorable dan unfavorable. Skala pengukuran adalah dengan menggunakan skala Likert dari skala 1 sampai dengan 4 dengan arti sebagai berikut 1 adalah sangat tidak setuju, 2 adalah tidak setuju, 3 adalah setuju, dan 4 adalah sangat setuju.

Dalam penelitian ini intensi pindah kerja karyawan diukur dengan menggunakan Turnover Intention Questionnaire yang dikembangkan berdasarkan teori Mobley (1986). Skala dalam alat ukur ini terdiri dari sepuluh item pernyataan yang terdiri dari pernyataan favorable dan unfavorable. Sementara skala pengukuran adalah dengan menggunakan skala Likert dari skala 1 sampai dengan 4 dengan arti sebagai berikut 1 adalah sangat tidak setuju, 2 adalah tidak setuju, 3 adalah setuju, dan 4 adalah sangat setuju.

Data yang sudah diperoleh akan diolah dengan menggunakan SPSS versi 24 untuk melihat peran kualitas kehidupan kerja dan persepsi peluang kerja terhadap intensi pindah kerja dengan menggunakan analisis regresi. Selanjutnya dilakukan analisis dengan melihat perbedaan nilai mean variabel berdasarkan jenis kelamin, usia, tingkat pendidikan, status pernikahan, dan masa kerja di PT. X. Analisis ini dilakukan untuk melihat ada atau tidaknya perbedaan pada variabel karakteristik partisipan di masing-masing variabel. Berdasarkan data karakteristik partisipan, untuk menguji perbedaan tersebut digunakan Uji $T$ Test jika variasi terdiri dari dua kelompok dan Uji One-Way Anova jika variasi terdiri lebih dari dua kelompok.

Uji asumsi dilakukan untuk menghindari munculnya bias dalam analisis data serta untuk menghindari kesalahan spesifik model regresi yang digunakan. Adapun pengujian terhadap asumsi-asumsi regresi linear meliputi uji normalitas dan uji korelasi.

\section{HASIL DAN PEMBAHASAN}

Hasil uji reliabilitas dan validitas pada skala kualitas kehidupan kerja untuk semua butir di masing-masing dimensi memenuhi kriteria yang telah disyaratkan sebelumnya. Butir-butir pada skala kualitas kehidupan kerja tidak ada yang digugurkan.Nilai reliabilitas total cronbach's alpha sebesar 0,928 dengan korelasi butir item $>0,361$ ( $r$ tabel) dan nilai validitas setiap butir antara 0,4 0,872 . Dengan demikian alat ukur yang digunakan reliable dan valid untuk mengukur kualitas kehidupan kerja di PT. X. 


\section{Journal of Psychological Science and Profesion (JPSP)}

Vol.1, No.1, Desember 2017

E-mail: jpsp@unpad.ac.id

Tabel 1. Gambaran Reliabilitas Alat Ukur Kualitas Kehidupan Kerja

\begin{tabular}{lcc}
\hline $\begin{array}{l}\text { Dimensi Kualitas } \\
\text { Kehidupan Kerja }\end{array}$ & $\begin{array}{c}\text { Jumlah } \\
\text { Butir }\end{array}$ & $\begin{array}{c}\text { Alpha } \\
\text { Cronbach }\end{array}$ \\
\hline Pay and Benefits & 5 & 0.813 \\
Working Condition & 3 & 0.701 \\
$\begin{array}{l}\text { Personal } \\
\text { Development }\end{array}$ & 4 & 0.807 \\
$\begin{array}{l}\text { Promotion } \\
\text { Co-Worker }\end{array}$ & 3 & 0.841 \\
Work Culture & 3 & 0.726 \\
Work Life Balance & 4 & 0.845 \\
$\begin{array}{l}\text { Social Relevance of } \\
\text { Employer }\end{array}$ & 5 & 0.746 \\
Supervisory & 5 & 0.848 \\
Job Characteristic & 7 & 0.794 \\
Reliability Total & 47 & 0.928 \\
\hline
\end{tabular}

Sementara pengujian terhadap reliabilitas dan validitas alat ukur persepsi peluang kerja menunjukkan hasil reliabilitas cronbach's alpha yang sangat tinggi yaitu sebesar 0,969 dan nilai validitas setiap butir antara $0,804-0,966$.

Pengujian terhadap reliabilitas dan validitas alat ukur intensi pindah kerja menunjukkan hasil reliabilitas cronbach's alpha yang sangat baik yaitu sebesar 0,874 dan nilai validitas setiap butir antara 0,422 - 0,877.

Gambaran kualitas kehidupan kerja menggunakan skala 1-5. Penjelasan lengkap dapat dilihat melalui tabel berikut:

Tabel 2. Gambaran Variabel Kualitas Kehidupan Kerja
Dari kesepuluh dimensi yang ada dalam variabel kualitas kehidupan kerja, dimensi promotion merupakan dimensi yang memiliki nilai mean empirik paling kecil diantara dimensi yang lain. Artinya, persepsi partisipan mengenai kesempatan untuk meningkatkan ataupun mengembangkan karir serta sistem reward dengan kenaikan jabatan cenderung kurang di PT. X. Sedangkan dimensi yang memiliki nilai mean empirik paling tinggi adalah work culture, dimensi ini memiliki nilai mean empirik yang lebih tinggi dari nilai titik tengah (3). Artinya, partisipan mempersepsikan bahwa karyawan diberi kebebasan dalam menentukan gaya bekerjanya ataupun keputusan yang akan diambil selama masih sesuai dengan visi misi perusahaan.

Variabel persepsi peluang kerja memiliki nilai minimum pada skala 1,6 dan nilai maksimum pada skala 3,4. Variabel persepsi peluang kerja memiliki titik tengah skala alat ukur yaitu 2,5 sedangkan mean empirik adalah 2,69. Skor mean empirik $(2,69>2,5)$ maka persepsi peluang kerja partisipan penelitian dapat dikatakan cenderung tinggi. Artinya, partisipan dalam penelitian ini merasa peluang kerja di luar PT. $X$ cukup besar.

Variabel intensi pindah kerja memiliki nilai minimum pada skala 1,9 dan nilai maksimum pada skala 5,0. Variabel intensi pindah kerja memiliki titik tengah skala alat ukur yaitu 2,5 sedangkan mean empirik adalah 2,68 . Skor mean empirik $(2,68>2,5)$ maka intensi pindah kerja partisipan penelitian dapat dikatakan cenderung tinggi. Artinya, partisipan dalam penelitian ini memiliki keinginan yang cenderung tinggi untuk berpindah kerja dari PT. $X$.

Uji normalitas data menggunakan One Sample Kolmogorov Smirnov. Artinya apabila nilai signifikansi data lebih besar dari 0,05 maka distribusi data dikatakan normal. Pada nilai residu variabel kualitas kehidupan kerja nilai Kolmogorov-Smirnov $Z=0,540$ dan $p=0,487>$ 0,05 artinya data terdistribusi normal. Kemudian pada nilai residu variabel persepsi peluang kerja nilai Kolmogorov-Smirnov $Z=0,291$ dan $p=$ $0,328>0,05$ artinya data terdistribusi normal. Dan pada nilai residu variabel intensi pindah kerja nilai Kolmogorov-Smirnov $Z=0,621$ dan $p=0,464>$ 0,05 artinya data terdistribusi normal. Jadi data terdistribusi normal untuk ketiga variabel penelitian.

Tujuan dari uji multikolinearitas yaitu untuk mengetahui ada atau tidaknya korelasi antar variabel independen dengan model regresi. Cara untuk melihat ada atau tidaknya masalah pada uji -multikolinearitas dengan melihat nilai tolerance 


\title{
Journal of Psychological Science and Profesion (JPSP)
}

\author{
Vol.1, No.1, Desember 2017 \\ E-mail: jpsp@unpad.ac.id
}

dan variance inflation factor (VIF). Nilai yang disarankan adalah tolerance harus lebih besar dari 0,10 dan VIF lebih kecil dari 10. Pada tabel 4.5 dapat disimpulkan bahwa data memenuhi uji asumsi multikolinearitas, sehingga pengolahan data dapat dilanjutkan dengan uji regresi.

Tabel 3. Hasil Uji Multikolinearitas

\begin{tabular}{lcc}
\hline \multicolumn{1}{c}{ Variabel } & $\begin{array}{c}\text { Nilai } \\
\text { Tolerance }\end{array}$ & $\begin{array}{c}\text { Variance } \\
\text { Inflation } \\
\text { Factor (VIF) }\end{array}$ \\
\hline Kualitas kehidupan kerja & 0.994 & 1.006 \\
Persepsi peluang kerja & 0.994 & 1.006 \\
\hline
\end{tabular}

Uji autokorelasi merupakan pengujian yang dilakukan untuk menguji ada tidaknya pengaruh antara variabel pengganggu dalam masingmasing variabel bebas. Uji yang dilakukan adalah uji Durbin Watson, hasil uji tersebut menunjukkan nilai perhitungan 2,042. Berdasarkan tabel Durbin Watson nilai yang dapat diterima adalah lebih besar dari 1,817, sehingga dapat disimpulkan bahwa data yang ada pada penelitian ini tidak terdapat masalah pada uji autokorelasi.

Untuk mengetahui peran kualitas kehidupan kerja terhadap intensi pindah kerja dilakukan uji regresi. Nilai $F$ sebesar 127,656 dengan signifikansi $(p)$ sebesar $0,000(p<0,05)$. Hal ini menunjukkan bahwa terdapat peran kualitas kehidupan kerja terhadap intensi pindah kerja. Dari hasil uji regresi didapatkan hasil bahwa nilai $R$ adalah sebesar 0,548 dan koefisien determinasi $R^{2}$ ( $R$ Square) adalah sebesar 0,300. Hal ini menunjukkan bahwa kualitas kehidupan kerja memberikan sumbangan peran sebesar $30 \%$ terhadap intensi pindah kerja. Selanjutnya untuk melihat secara detil uji regresi setiap dimensi kualitas kehidupan kerja terhadap intensi pindah kerja, maka dapat dilihat pada tabel 4.

Hasil yang didapat pada $\mathrm{R}$ Square dan Standardized Coefficients (Beta) dari tiap dimensi kualitas kehidupan kerja terhadap intensi pindah kerja menunjukkan bahwa personal development memiliki kontribusi peran paling besar terhadap intensi pindah kerja.

Untuk mengetahui peran persepsi peluang kerja terhadap intensi pindah kerja maka dilakukan uji regresi. Nilai $F$ sebesar 11,578 dengan signifikansi $(p)$ sebesar 0,001 ( $p<0,05)$. $\mathrm{Hal}$ ini menunjukkan bahwa terdapat peran persepsi peluang kerja terhadap intensi pindah kerja. Dari hasil uji regresi didapatkan hasil bahwa nilai $R$ adalah sebesar 0,193 dan koefisien determinasi $R^{2}$ (R Square) adalah sebesar 0,037. Hal ini menunjukkan bahwa persepsi peluang kerja memberikan sumbangan peran sebesar 3,7 $\%$ terhadap intensi pindah kerja.

Tabel 4. Nilai Uji Regresi Tiap Dimensi Kualitas Kehidupan Kerja

\begin{tabular}{|c|c|c|c|c|c|}
\hline Dimensi & Nilai F & $\begin{array}{l}P \\
\text { value }\end{array}$ & $\begin{array}{l}\text { Nilai R } \\
\text { Square }\end{array}$ & $\begin{array}{l}\text { Nilai } \\
\text { Beta }\end{array}$ & Interpretasi \\
\hline Pay and Benefits & 11.477 & 0.01 & 0.037 & -0.193 & $\begin{array}{l}\text { Memiliki peran terhadap } \\
\text { intensi pindah kerja sebesar } \\
3,7 \%\end{array}$ \\
\hline Working Condition & 20.113 & 0.00 & 0.063 & -0.251 & $\begin{array}{l}\text { Memiliki peran terchadap } \\
\text { intensi pindah kerja sebesar } \\
6,3 \%\end{array}$ \\
\hline $\begin{array}{l}\text { Personal } \\
\text { Development }\end{array}$ & 371.603 & 0.00 & 0.555 & -0.745 & $\begin{array}{l}\text { Memiliki peran terchadap } \\
\text { intensi pindah kerja sebesac } \\
55,5 \%\end{array}$ \\
\hline Promotion & 40.847 & 0.00 & 0.121 & -0.347 & $\begin{array}{l}\text { Memiliki peran terbadap } \\
\text { intensi pindah kerja sebesar } \\
12,1 \%\end{array}$ \\
\hline Co-Worker & 21.219 & 0.00 & 0.066 & -0.258 & $\begin{array}{l}\text { Memiliki peran terbadap } \\
\text { intensi pindah kerja sebesar } \\
6,6 \%\end{array}$ \\
\hline Constitutionalism & 18.851 & 0.00 & 0.059 & -0.244 & $\begin{array}{l}\text { Memiliki peran terchadap } \\
\text { intensi pindah kerja sebesar } \\
5,9 \%\end{array}$ \\
\hline Work Life Balance & 0.003 & 0.954 & 0.00 & -0.003 & $\begin{array}{l}\text { Tidak memiliki peran terhadap } \\
\text { intensi pindah kerja }\end{array}$ \\
\hline $\begin{array}{l}\text { Social Relevance of } \\
\text { Employer }\end{array}$ & 0.16 & 0.689 & 0.001 & 0.023 & $\begin{array}{l}\text { Tidak memiliki peran terbadap } \\
\text { intensi pindah kerja }\end{array}$ \\
\hline Supervisory & 31.519 & 0.00 & 0.096 & -0.309 & $\begin{array}{l}\text { Memiliki peran terbadap } \\
\text { intensi pindah kerja sebesar } \\
9,6 \%\end{array}$ \\
\hline Job Characteristic & 173.209 & 0.00 & 0.368 & -0.606 & $\begin{array}{l}\text { Memiliki peran terhadap } \\
\text { intensi pindah kerja sebesar } \\
36,8 \%\end{array}$ \\
\hline
\end{tabular}

Hasil dari analisis diperoleh bahwa nilai regresi variabel kualitas kehidupan kerja dan persepsi peluang kerja terhadap intensi pindah kerja memiliki nilai $F$ sebesar 70,780 dengan signifikansi ( $p)$ sebesar 0,000 ( $p<0,05)$. Artinya bahwa Ho ditolak dan $\mathrm{H} 1$ diterima sehingga terdapat peran yang signifikan antara kualitas kehidupan kerja dan persepsi peluang kerja terhadap intensi pindah kerja. Nilai $R^{2}$ ( $R$ Square) adalah 0,323 artinya sumbangan kualitas kehidupan kerja dan persepsi peluang kerja terhadap intensi pindah kerja adalah 32,3\%, sedangkan sisanya $67,7 \%$ dipengaruhi faktor lain.

Berdasarkan Skor Standardized Coefficients (Beta), dapat diungkapkan bahwa kualitas kehidupan kerja lebih berperan terhadap intensi pindah kerja dibandingkan dengan persepsi peluang kerja. Hal ini karena nilai beta kualitas kehidupan kerja lebih tinggi daripada persepsi peluang kerja. Nilai beta setiap variabel dapat dilihat pada tabel berikut ini.

Tabel 5. Nilai Beta Tiap Variabel

\begin{tabular}{cc}
\hline Variabel & Nilai Beta \\
\hline Kualitas Kehidupan Keria & -0.536 \\
Persepsi Peluang Kerja & 0.152 \\
\hline
\end{tabular}




\title{
Journal of Psychological Science and Profesion (JPSP)
}

\author{
Vol.1, No.1, Desember 2017 \\ E-mail: jpsp@unpad.ac.id
}

\section{SIMPULAN}

Berdasarkan hasil analisa data diperoleh hasil bahwa kualitas kehidupan kerja memiliki peran terhadap intensi pindah kerja karyawan PT. X. Hasil penelitian ini menunjukkan hasil yang sama dengan penelitian yang sebelumnya yang dilakukan oleh Kumar dan Thomas (2016), Rokhman (2013), Mosadeghrad (2013), dan Almalki, FitzGerald dan Clark (2012).

Dimensi kualitas kehidupan kerja yang memiliki peran cukup besar dalam penelitian ini adalah personal development dan job characteristic. Personal development adalah kemungkinan berkembang dalam kemampuan kerja dan kesempatan menggunakan keterampilan atau pengetahuan baru yang dimiliki. Dengan menyadari bahwa perubahan pasti terjadi dimasa depan, ada jaminan bahwa pekerjaan dan penghasilan seseorang tidak akan hilang. Sedangkan job characteristic adalah keleluasaan karyawan dalam bekerja, kejelasan tanggung jawab pekerjaan, dan beban kerja yang tidak berlebihan. Hasil penelitian ini memiliki hasil yang sama dengan penelitian Kumar dan Thomas (2016). Hasil penelitian Kumar dan Thomas (2016) adalah management support, job characteristic, job security, job stress, dan promotion policy. Oleh karena itu dapat dikatakan bahwa dimensi kualitas kehidupan kerja yang dihasilkan oleh penelitian ini sudah ada di hasil penelitian yang dilakukan sebelumnya. Sedangkan untuk perbedaan hasil penelitian dimensi kualitas kehidupan kerja lainnya yang memiliki peran cukup besar terhadap intensi pindah kerja tetapi tidak berperan besar di hasil penelitian ini adalah supervisory, co-worker, pay and benefits, dan working condition. Keadaan ini dapat dikarenakan karakteristik sampel yang bervariasi. Penelitian sebelumnya memiliki variasi sampel yang cukup banyak karena mengambil sampel dari berbagai perusahaan sedangkan penelitian ini hanya menggunakan sampel karyawan media cetak di PT. X.

Jika dilihat dari nilai mean empirik dimensi personal development dan job characteristic, dapat dikatakan keadaan dimensi ini cenderung rendah. Keadaan ini juga terjadi pada hasil penelitian Kumar dan Thomas (2016), dimana karyawan merasa bahwa kedua dimensi tersebut cenderung rendah. Sedangkan pada penelitian yang lain dimana dimensi personal development dan job characteristic juga berperan, karyawan juga merasa bahwa kedua dimensi tersebut cenderung rendah. Artinya, peluang pengembangan diri melalui pelatihan ataupun sekolah serta pengaplikasian keterampilan atau ilmu yang dimiliki dinilai oleh karyawan kurang memadai. Sama hal nya dengan keleluasaan karyawan dalam bekerja, kejelasan tanggung jawab pekerjaan, dan beban pekerjaan dinilai karyawan masih belum dirasa adil.

Selain itu jika dianalisa dengan Teori Pertukaran Sosial, maka hasil penelitian ini mendukung teori yang dikembangkan oleh Hommans, bahwa adanya interaksi hubungan timbal balik antara karyawan dan perusahaan. Imbalan atau penghargaan yang merupakan bagian dari kualitas kehidupan kerja dianggap kurang oleh karyawan sehingga mengakibatkan keinginan pindah kerja karyawan di PT. X tinggi.

Selain variabel kualitas kehidupan kerja, hasil penelitian menunjukkan bahwa variabel persepsi peluang kerja juga memiliki peran terhadap intensi pindah kerja pada karyawan PT. X. Penelitian sebelumnya yang dilakukan oleh Treuren (2013) dan Laker (2011) mengenai hubungan antara persepsi terhadap peluang kerja dan intensi pindah kerja, menyatakan bahwa persepsi peluang kerja terhadap intensi pindah kerja memiliki hubungan secara signifikan. Penelitian ini memiliki hasil yang sama dengan penelitian yang sudah dilakukan sebelumnya akan tetapi dengan kontribusi peran yang berbeda.

Secara umum menunjukkan bahwa kontribusi peran persepsi peluang kerja terhadap intensi pindah kerja cukup jauh berbeda dan lebih kecil jika dibandingkan dengan penelitian sebelumnya. Jika dibandingkan dengan penelitian Laker (2011), persepsi peluang kerja dikembangkan menjadi beberapa dimensi, sehingga lebih detil dan spesifik dalam meneliti variabel persepsi peluang kerja. Sedangkan dalam penelitian ini variabel persepsi peluang kerja tidak memiliki dimensi, sehingga pengukuran untuk variabel ini lebih bersifat umum. Akibatnya kontribusi peran persepsi peluang kerja di penelitian Laker (2011) lebih besar dibandingkan penelitian ini. Selain itu jika dibandingkan dengan penelitian Treuren (2013), waktu pengambilan data yang dilakukan adalah dua periode waktu tertentu sehingga hasil penelitian dapat lebih akurat dan bervariasi. Sedangkan penelitian ini hanya satu periode waktu tertentu. Oleh karena itu hasil penelitian di PT. X memiliki kontribusi peran lebih kecil jika dibandingkan dengan penelitian Treuren (2013).

Berdasarkan hasil penelitian menunjukkan bahwa kualitas kehidupan kerja dan persepsi peluang kerja memiliki peran terhadap intensi pindah kerja. Sejauh ini peneliti belum 


\title{
Journal of Psychological Science and Profesion (JPSP)
}

\author{
Vol.1, No.1, Desember 2017 \\ E-mail: jpsp@unpad.ac.id
}

menemukan penelitian yang mengukur kedua variabel tersebut terhadap intensi pindah kerja. Oleh karena itu hasil penelitian ini menunjukkan bahwa kualitas kehidupan kerja dan persepsi peluang kerja dapat secara bersamaan berperan terhadap intensi pindah kerja. Hasil penelitian ini dapat memperkaya hasil penelitian yang berhubungan dengan variabel kualitas kehidupan kerja, persepsi peluang kerja, dan intensi pindah kerja. Keterbatasan penelitian ini menunjukkan hasil yang bervariasi terhadap hasil penelitian sebelumnya.

Penelitian berikutnya dapat mengukur mengenai dengan keadaan PT. $X$ saat ini dimana PT. $X$ tidak siap menerima persaingan yang ada sehingga tidak mampu mengantisipasi keadaan. Penelitian dapat berkaitan dengan bagaimana perusahaan dapat melakukan transformasi dari media cetak ke media digital, variabel apa saja yang dapat diteliti dari keadaan ini sehingga hasil penelitian dapat menjadi masukan yang berguna bagi perusahaan.

\section{SARAN}

Cara perusahaan dapat menurunkan intensi pindah kerja karyawan dari PT. X maka perusahaan dapat kembali melaksanakan program pelatihan khususnya untuk bagian Editorial yang merupakan unit bisnis utama dari perusahaan ini. Apalagi saat ini karyawan di bagian Editorial sedang mengalami gejolak atau perubahan gaya kerja dari yang biasanya menulis untuk di majalah sekarang menjadi menulis juga untuk di website atau sosial media. Pelatihan yang mungkin dapat dilakukan pertama kali adalah Pelatihan Digital. Pelatihan ini diberikan kepada karyawan sebagai bekal bagi mereka untuk memahami dunia digital tersebut secara umum dan kemudian pengaplikasiannya di pekerjaan mereka sehari-hari.

Selain intervensi tersebut, untuk mengatasi mengenai ketidakjelasan uraian dan tanggung jawab pekerjaan, PT. $X$ dapat mulai kembali mengadakan rencana kerja. mengadakan kembali work plan tahunan yang dilanjutkan dengan performance appraisal. Mungkin perusahaan tidak mampu untuk memberikan kenaikan gaji kepada seluruh karyawan, tapi hal ini dapat disiasati dengan mengubah sistem penilaian kinerja. Misalnya, karyawan yang nilai kinerjanya berada di sepuluh besar teratas adalah karyawan yang memperoleh kenaikan gaji atau reward. Sehingga karyawan menjadi memiliki motivasi untuk bekerja, mereka memiliki target yang harus dicapai. Rencana kerja yang awalnya sudah disusun pada akhirnya dapat dijadikan acuan bagi karyawan untuk mencapai target mereka sehingga pekerjaan dapat berjalan sesuai waktu yang ditentukan dan sejalan dengan visi dan misi perusahaan. Selain itu, perusahaan juga dapat mulai membenahi struktur organisasi setiap bagian dan merevisi uraian pekerjaan setiap posisi sesuai dengan kebutuhan perusahaan saat ini, sehingga karyawan baru ataupun karyawan yang di mutasi dapat mengerti dengan jelas tanggung jawab pekerjaannya. Kejelasan tersebut dapat memudahkan karyawan menyelesaikan pekerjaannya sehingga membuat karyawan bersemangat untuk bekerja. Jika keadaan keadaan tersebut terlaksana, maka intensi karyawan PT. $X$ untuk pindah kerja akan berkurang.

Karyawan diharapkan dapat mengoptimalkan penghargaan serta sarana pendukung yang telah diberikan oleh perusahaan. Seperti program pelatihan, rencana kerja, kejelasan tanggung jawab, serta hal lainnya yang diberikan perusahaan kepada karyawan. Karyawan tidak hanya menuntut untuk meminta penghargaan atas pekerjaannya tetapi juga berusaha sendiri mengoptimalkan keterampilannya dan juga menggunakan keterampilan tersebut secara maksimal dalam pekerjaannya.

\section{DAFTAR PUSTAKA}

Homans, George C. (1958). Social Behavior as Exchange, American Journal of Sociology 63: 597-606.

Hongvichit, S. (2015). The research progress and prospect of employee turnover intention. International Business Research, 8(6), 218 $-223$.

Jackson, S. E., Schuler, R. S., \& Werner, S. (2012). Managing human resources. Cengage Mason: $\mathrm{OH}$.

Jaidev, U. P. (2013). Socio-psychological determinants of quality of work life among academicians. International Journal of Science and Research, 4(8), 2039 - 2043.

Kaur, A. (2016). Quality of work life. International Journal of Engineering Science and Computing, 6(7), 8305 - 8311.

Melky, Y. (2015). Hubungan kepuasan kerja dan komitmen organisasi terhadap intensi pindah kerja karyawan PT. Rejeki Abadi Sakti Samarinda. Jurnal Psikologi, 3(3), $694-707$. 
Journal of Psychological Science and Profesion (JPSP)

Vol.1, No.1, Desember 2017

E-mail: jpsp@unpad.ac.id

Mobley, W.H. (1986). Pergantian Karyawan: Sebab, Akibat, dan Pengendaliannya. Terjemahan. Jakarta: PT. Pustaka Binaman Pressindo.

Putri, A. D. (2017). Peran kualitas kehidupan kerja, pemberdayaan psikologis, dan persepsi peluang kerja terhadap intensi kindah Kerja. Jakarta: Universitas Tarumanagara.

Robbins, S., P. \& Judge, T., A. (2009). Organizational behavior. USA: Pearson International Edition, Prentice - Hall.

Rostiana, Zamralita, \& Suyasa, P. T. Y. S. (2014). Alat ukur quality of work-life. Lembaga Penelitian dan Publikasi IImiah, Universitas Tarumanagara, Jakarta.

Rostiana, Zamralita, \& Suyasa, P. T. Y. S. (2014). Alat ukur turnover intention. Jakarta.

Sadri, S. \& Goveas, C. (2013). Sustainable quality of work life and job satisfaction. Journal of Economic Development, Environment and People, 2(4), 26 - 37.

Saeed, I., Sikander, S., \& Waseem, M. (2014). The relationship of turnover intention with job satisfaction, job performance, leader member exchange, emotional intelligence and organizational commitment. International Journal of Learning \& Development, $\quad 4, \quad 242-256$. doi:10.5296/ijld.v4i2.6100

Samad, S. (2006). The contribution of demographic variable: Job characteristics and job satisfaction on turnover intention. Journal of International Management Studies, 1(1), 1 - 10.

Sheel, S., Sindhwani, B. K., Goel, S., \& Pathak, S. (2012). Quality of work life, employee performance, and career growth opportunities: A literature review. International Journal of Multidisciplinary Research, 2(12).

Walton, R. E. (1973). Quality of Working Life: What Is It?, Sloan Management Review 15(1): 11-21. 